\title{
Creating and Reinforcing Discrimination: The Controversial Role of Accounting in Bank Lending
}

\author{
Candauda Arachchige Saliya \\ Business School \\ Auckland University of Technology \\ Auckland \\ New Zealand
}

Kelum Jayasinghe*

Essex Business School,

University of Essex.

United Kingdom

* Correspondence: 
E-mail: knjay@essex.ac.uk

Tel: +44 (0) 1206874281

Fax: +44 (0) 1206873429

\title{
Creating and Reinforcing Discrimination: The Controversial Role of Accounting in Bank Lending
}

\begin{abstract}
This paper examines the controversial role played by accounting within the discriminatory bank-lending practices of a privately owned bank in Sri Lanka. It reports on an analytical auto-ethnography (during the period 1994-2004) coupled with follow-up interviews and reiterated analyses. Data were analysed using Pierre Bourdieu's concepts of field, capital, habitus and symbolic violence. The empirical findings of the paper illustrate how key capitals at macro levels (social, cultural and symbolic) are mobilised in the dominance structures within the banking lending field and how individuals with given habitus behave and follow given strategies to deploy rational accounting systems at a micro level to translate discriminatory bank lending policies into practice and, as a result, create and reinforce discrimination.
\end{abstract}

Keywords: Accounting and discrimination; Bank lending; Bourdieu; Capital, Habitus; Symbolic violence; Domination, Sri Lanka

\section{Introduction}

This paper stems from a concern over accounting and discriminatory bank lending. There has been some interest amongst accounting researchers in exploring the controversial role of accounting in discriminatory practices. Thus, Boltanski and Chiapello (2005), Puxty (1986), and Tinker et al. (1991) explained the role of accounting in "discrimination" and clarified how class struggles have 
been practiced within the discourse of corporate social responsibility (CSR). Further, Neu (2000), Davie (2002), and Fleischman and Tyson (2004) provide observations on how accounting techniques used on the British West Indies (BWI) plantations provided examples of employment of racist policies in controlling labour, productivity and costs. What has been relatively ignored in this emerging research is how the accounting techniques help to translate "discriminatory banking lending policies" into practice. This paper contributes to filling this perceived gap.

Previous studies have highlighted that a nexus exists between accounting and discrimination. For instance, Fleischman and Tyson (2000) analysed the interface of race and accounting and concluded that race, rather than efficiency, served as the primary measuring calculus of plantation work. In a later study Fleischman and Tyson (2004) illustrated how accounting served slavery and its institutions through measurement, valuation and classification techniques that completely ignored the qualitative and human dimensions of slavery. Neu (2000) explained how accounting techniques helped to translate policies of conquest, annihilation, containment and assimilation into practice, with the resultant outcomes of reproductive genocide, cultural genocide and ecocide. Moreover, Davie (2002) highlighted accounting's involvement in race relations and revealed how the invention of new afforestation accounting practices helped to create and perpetuate differentiated, racialised identities of social and economic relations. The issue of discriminatory accounting becomes even more important when accounting became engaged in, and facilitated, discriminatory mobilisation of financial capital, particularly in the context of bank lending in emerging economies. Thus, this paper investigates the accounting-discrimination nexus in the context of the bank-lending practices of a privately owned bank in Sri Lanka. Thus, it explores the research issue: how accounting helps to translate discriminatory bank lending policies into practice and reinforce discrimination. 
The theoretical perspective of this paper draws on the work of Pierre Bourdieu (1996). It uses the tools of Bourdieu and his distinction between the dominant and the dominated (symbolic violence) and how that influences habitus (and therefore practice) to understand the accounting and discrimination issues in bank lending that the current accounting literature does not address. It uses multiple sources of evidence, including an auto-ethnography of a close-held bank in Sri Lanka, built around participant observations and the life experiences of one of the authors (during the period 1994-2004); semi-structured interviews with the participants in those historical events; documents and archival records; openended questionnaires, internet conversations and exchanges of e-mails. The paper applies Bourdieu's (2007) "sketch for self-analysis" framework and his concepts such as symbolic violence, habitus and domination to analyse the autoethnographic data.

The remainder of this paper is organised as follows. Section 2 presents a literature review of accounting and discrimination, and combines it with the context of the bank lending developed from finance and banking literature. The theoretical framework is discussed in Section 3, while Section 4 provides a description of the research methods. In Section 5, the banking lending context of Sri Lanka is briefly presented. Section 6 presents the macro issue of mapping the field (as Bourdieu's methodology does) - what constitutes the dominant and what/who is the dominated in this field (what key capitals are mobilised in that dominance) - and how does this field relate to the key fields of power. Section 6 then progresses onto exploring the micro practices - how individuals with a given habitus behave and follow given strategies which have the effect of creating and reinforcing discrimination. Finally, Section 7 draws conclusions.

\section{Related literature on accounting and discrimination}


During recent decades, individuals, organizations and governments have become subject to more frequent calls for greater rationality and also for the adoption of more clearly defined lines of responsibility and accountability (Porter, 1992). As a consequence, accounting practices have assumed a status beyond levels previously recognised and have taken over the role of creating "financial" forms of visibility and rationality for abstract social and organizational lives (Hopwood, 1992; Miller \& Napier, 1993). Moreover, accounting and financial relations are expected to make a domain of behaviour visible and amenable to people's intervention but also provide the information upon which subsequent interventions can be based (Preston et al., 1997). For example, Preston et al. (1997) illustrated how accounting and financial relations were an invisible, but powerful, method of rationing the provision of healthcare services to the elderly in the United States. These studies and others (e.g., Power, 1994; Neu \& Taylor, 2000; Neu et al., 2006) illustrate how accounting and financial relations, along with other administrative techniques such as the rule of law, have been used to translate abstract financial policies into practice. Neu et al. (2006) revealed how the "informing" technologies, including recommended accounting practices embedded within lending agreements of the World Bank and the IMF, make the objects of governance knowable in terms of accounting and financial expertise and enable, translate and regulate the behaviour of loan recipients.

Moreover, some accounting researchers (Boltanski \& Chiapello, 2005; Puxty, 1986; Tinker et al., 1991) have focussed on accounting's role in "discrimination" and explained how the class struggles have been practiced within the discourse of CSR with the support of accounting language. They argued that the privileged/dominant groups generally succeed in legitimising their own agendas as superior to those of the lower classes through use of accounting language and communication. More critically, Fleischman and Tyson (2000) explored the interface of race and accounting by using a case study on Hawaiian sugar 
plantations during the $1835-1920$ period. They reviewed the accounting techniques used on the plantations and provided examples of employment of racist policies in controlling labour, productivity and costs. However, they did not find records on individual-specific productivity performance and concluded that race rather than efficiency served as the primary measuring calculus of plantation work. In another study, Fleischman and Tyson (2004) adopted a more critical perspective of accounting's past and examined its particular role in the commodification, objectification and dehumanization of an entire class of people (slaves) for more than 200 years. The study illustrated how accounting served slavery and its institutions through measurement, valuation and classification techniques that completely ignored the qualitative and human dimensions of slavery. Based on a study regarding colonization and genocide of Canada's First Nations, Neu (2000) argued that the government employed accounting tactics to arrange things in such a way that certain ends could be achieved. His study focused on how accounting techniques functioned as a "software" of imperialism and technology serving the ruling government to change the relationship of indigenous people to their land. Their analyses highlight how accounting techniques helped to translate policies of conquest, annihilation, containment and assimilation into practice, with the resultant outcomes of reproductive genocide, cultural genocide and ecocide. With regard to accounting's involvement in race relations, Davie's (2002) case study of the Fijian pine industry demonstrates how "invention of new afforestation accounting practices help to create and perpetuate differentiatory, racialised identities of social and economic relations". The findings of this study suggest that affirmative action policies and initiatives constitute a form of racism.

The above literature illustrates the controversial role of accounting in facilitating discrimination. However, the current literature on accounting and discrimination has not made much effort towards understanding how accounting engages in and facilitates "discriminatory mobilisation" of financial capital, particularly in the 
context of bank lending. Many banking and finance researchers are of the view that access to credit is limited to certain groups of society and that it is primarily the rich and well connected who would benefit from advancements in the financial system (Haber, 2004; Zhuang et al., 2009). As stated by the Governor of the Bank of England: "A particular problem at this end of the scale is access to start-up or early-stage finance for disadvantaged groups in poor neighbourhoods" (Bank of England, 1999, p. 207). There was a further revelation that budding entrepreneurs from different demographic and ethnic groups, such as Black and Hispanic, do not have similar opportunities to access finance, and thus some have less while other groups have more access to financial capital (Cavalluzzo, Cavalluzzo, \& Wolken, 2002). However, the controversial role of accounting in this discriminatory bank lending context remains under-researched.

\section{Bourdieu's theories of symbolic violence, habitus and domination}

The paper uses Bourdieu's (Bourdieu, 1972, 1977, 1980, 1994) conceptualisation of symbolic violence, habitus and domination to understand how the dominant actors in the bank lending field secure their influence in discriminatory lending decisions and how they manage to reinforce discrimination. Bourdieu (1977) proposed the notions of field, capital and habitus to understand the static and dynamic aspects of an institutional field. According to Bourdieu (1998), field is characterized by force and struggles where individuals attempt to create a dominant mode of practice. At stake in the field is the accumulation of capital; this is both the process within and the product of the field. Bourdieu (1984) refers the field as a theoretical space constructed by discourse. In each field, the agents are categorised by their possession of a particular combination of properties which function as some form of capital, e.g., economic, cultural, political, symbolic, and then the forms of unequally shared capital create different power positions and relations within the field (Everett, 2002). The conflicts and competition arise between actors when they attempt to accumulate different types 
of capital. The amounts of capital possessed by individual actors then determine the dynamic power positions and relations in the field, such as dominance, subordinance or equivalence (Everett, 2002). He uses the term symbolic capital to include such types of capital as cultural, linguistic, scientific and literary, depending on the field in which they are located. Symbolic capital can be considered as the resources available to an individual on the basis of honour, prestige or recognition, and serves as the value that one holds within a culture. It can be considered as a transubstantiated form of economic capital (Bourdieu, 1984). Bourdieu (1984) refers to habitus as a real political space constituted by agents' actions (Bourdieu, 1998). Habitus organises practices and the perception/evaluation of practices and the dispositions for acting, internalised by the individuals themselves within a field (Bourdieu, 1984). In other words, habitus is embodied within individual social actors and operates as a structuring mechanism that generates strategies for actions in the field (Everett, 2002). For Bourdieu (1977), the struggle is played out between the dominated, who wish to challenge collective habitus or taken-for-granted dispositions (doxa) within a given field, and the dominant, who wish to defend it. This logic of practices is internalized as second nature, and forgotten as history (Bourdieu, 1990). Essentially, when dominant practices are naturalized and appear as a self-evident or basic and common way of organising various aspects of personal and professional lives, they are referred to as doxa (Bourdieu, 1977, 1998). Doxa represents socially accepted misconceptions that transfer to people through their socialization. According to Bourdieu, Doxa is formed by arguments and can be also used as a tool to form arguments.

Bourdieu's theory presents a critical explanation to the concepts of power and domination and discuss the relationship between dominant and dominated (Bourdieu, 1980). Bourdieu reconnoitres the efforts and conflicts of individuals to generate a dominant mode of practice and the ways that domination and power provide individuals with capital and create their identities. According to Bourdieu 
(1980), language and symbolic systems are instruments of, not only knowledge and communication, but also domination. Thus, powerful actors use languages such as accounting to construct specific meanings and interpretations and impose their own logic as acceptable, to the extent that they control the resource appropriation decisions over the dominated (Bourdieu, 1976, 1980, 1992; Everett, 2002). In this perspective, by providing rational meanings for discriminatory lending decisions, accounting applies symbolic power and defines the patterns of domination, so that dominant groups can exploit the mechanisms of the field (Everett, 2002). Moreover, symbolic power which promotes a hierarchy as legitimate is embodied in the habitus and contributes to the reproduction of domination (Everett, 2002). This reproduction of the dominant's interest creates some form of stability for irregularities in their power positions (Malsch et al., 2011) and by transforming petty personal interests (of dominant groups) into "collective interests" or "disinterests" that become "generally accepted" (Bourdieu, 1977, 1980, 1994). In other words, accounting language and techniques help symbolic violence to legitimise the reproduction of uneven positions of power by shaping what is agreeable or what is not. Bourdieu's concept of symbolic violence explains how order and restraint are established and maintained through indirect cultural mechanisms, as opposed to direct, coercive control (Bourdieu \& Wacquant, 1992).

In summary, this paper uses Bourdieu's conceptualisations to analyse how accounting redefines legitimate forms of capital and shapes habitus in the bank lending field. The paper's analysis illustrates how the dominant group in the banking lending field uses accounting to translate discriminatory bank lending policies into practice and reproduce the conditions for its domination, masked by a discourse of consensus.

\section{Research methodology}


Bourdieu (2007), in his book, Sketch for a Self-Analysis introduces a clear research methodology - mapping the field and exploring the practices within the field. In this book, he uses the theoretical concepts devised over his career in a reflective socio-analysis of himself and illustrates the intellectual field that lay before him as a young intellectual (Everett, 2002). Bourdieu (2007) describes his formation of the dispositions that ultimately led him to sociology despite a variety of other possible careers. Bourdieu considers research has two important roles: to reveal the hidden mechanisms of domination and to publish research beyond the academic field (Neu et al., 2006). According to Malsch et al. (2011), Bourdieu allows researchers to gain a better understanding of accounting as a field that participates in a process of domination, especially with regard to professionalization and accounting regulation. Moreover, Bourdieu's theory as a methodology helps to uncover the hidden mechanisms and taken-for-granted power relations and explain how domination is reproduced. For researchers, Bourdieu (2007) proposes three steps which could be used to investigate a given field. First, he suggests analysing the position of the field, in terms of other fields, as a field of power. In this respect, the control of credit by banks in Sri Lanka makes bank lending a very powerful and most visible field in terms of overall power relations within Sri Lankan society. This makes the context of the privately owned bank and credit culture in Sri Lanka such a good setting to explore and obtain field-level evidence on how accounting sustains and reinforces discrimination. Second, he calls for mapping out the structure of relations between social agents and institutions which compete for authority within the field. This involves the macro issue of mapping the field (as Bourdieu does) - what is the dominant and what is the dominated in this field and what are the key capitals of the bank lending field mobilised in that dominance - and how does this bank lending field relate to key fields of power such as the symbolic. Third, Bourdieu suggests an analysis of the habitus of social agents and the different dispositions they have acquired through internalizing their social and economic conditions. This level of analysis focusses on exploring the micro 
practices of bank lending and how individuals with a given habitus behave and follow given strategies (which have the effect of sustaining and reinforcing discrimination). Here Bourdieu's (1976, 1980, 1992) ideas provide a good initial basis for explaining how and why this discrimination occurs in the bank lending field. Thus the data analysis of this paper is informed by Bourdieu's conceptualisation of symbolic violence, habitus and domination.

For the collection of data from the bank lending field, the study stems from the personal experience of one of the authors. It adopts an analytical autoethnography of a close-held bank in Sri Lanka as its main research method. Based on one of the author's recollection of accounts and insights (during the period 1994-2004), two case studies have been developed for subsequent analysis (Silverman, 1997; Yin, 2003). Data collection was carried out by reconstruction of participants' own experiences and recollection of accounts (the researcher and two other research participants) and those of 18 other bank staff (former colleagues of one of the authors), with questionnaires and interviews. There were over 20 interviewees in total. As one of the authors was present as a regular participant at board meetings of the Soft Bank, the decision-making procedures at the highest level of decision-making authority were observed. Reconstruction of the researcher's own experience occurred from 1994 to 2003. The other participants (interviewees) had worked in banks throughout their careers and had held various positions ranging from teller to chief manager (a middle-level position). The other colleagues/interviewees were contacted where necessary for cross-checking. Reconstruction of direct observations and events "connected with personal experience" (Wolcott, 1994, p. 44) were primary sources of data collection in the research. A set of guidelines provided by Crawford and others (Crawford, Kippax, \& Onyz, 1992, cited in Stephenson \& Papadopoulous, 2006, p. 58) was followed, to document the life experiences of the participants. The research participants, including one of the authors, were the account managers for the identified cases and had adequate data to use as case evidence. Based on the 
Interview Guidelines (see Appendix 1), they were encouraged to describe in as much detail as possible, the series of events and incidents they had observed and/or experienced during the period 1994-2004. Cross-checking with the other 18 colleagues/interviewees occurred. In the second case, all individuals involved in the credit decision were able to be interviewed which included the: branch manager, the credit manager, recovery manager (I) and the senior recovery manager (II). The details of the data collected from these participants are provided in Appendix 2.

Auto-ethnographies are commonly used in organisational studies although the method is relatively uncommon in accounting research (e.g., Grey \& Sinclair, 2006; Ford \& Harding, 2008; Ford, Harding, \& Learmonth, 2010; Humphreys \& Learmonth, 2010; Karra \& Phillips, 2008; Keenoy \& Seijo, 2010; Watson, 1995, 2008). As Anderson (2006) cited, auto-ethnography gained popularity in traditionally realist qualitative journals such as the Journal of Contemporary Ethnography, Symbolic Interactions, Qualitative Sociology; in post-modern journals such as Qualitative Inquiry; and handbooks and book series such as Handbook of Qualitative Inquiry and Ethnographic Alternatives. According to Ellis (2004), Butler (2009) and Learmonth and Humphreys (2012), autoethnography is a qualitative (interpretive) methodology that offers a particular way to situate oneself within the research process and its written product by making oneself the object of research and by developing a reflective connection between the researcher's and participants' lives. It narrates an autobiography ethnographically because it involves writing about the person's past and present experiences even though at the time of their occurrence there was no intention of publishing the details of the event. These experiences are assembled using hindsight assisted by interviewing related persons and consulting other supporting evidence in the form of recorded documents. Because of the undeniably reflective relationship between the seeker and what is being sought, 
auto-ethnography adds authenticity, genuineness and provides a faithful representation of the actual situation (Ellis, 2004).

However, the auto-ethnographic method faces some criticism from fellow qualitative researchers. They claim that auto-ethnographers are using personal experience and so they use supposedly biased data (Anderson, 2006). Madison (2006) argues that auto-ethnographers are navel-gazers, self-absorbed narcissists who do not fulfil the scholarly obligations of hypothesizing, analysing and theorising. Responding to this critique, Pelias (2000) and Ellis et al. (2011) contend that auto-ethnographers acknowledge the need for rigour, theory and analysis in research but they also recognize the need to include elements of emotion, therapeutics and phenomena both from social and personal points of view which necessitates the writing and research in general to be evocative and aesthetic. Anderson (2006) also claimed that analytical auto-ethnographies published in organizational studies (such as the one adopted in this study), are always committed to an analytical agenda. Different to the evocative autoethnography that captures what is going on in an individual life and social environment, analytical auto-ethnography provides an insider's perspective or evokes emotional resonance within the reader and offers insights into some broader set of social phenomena than those provided by data themselves (Anderson, 2006). As Chang (2007) identified, analytical auto-ethnography methodology enhances cultural understanding of self and others and creates a space for self-reflection and self-examination. The authors of this paper believe that these characteristics and the strengths of auto-ethnography methodology provide better insights into the behaviour of social actors in the bank-lending field in Sri Lanka. In order to understand the habitus and idiosyncrasies of individual actors and also to analyse the influence of competing capital, researchers require access to real life events in the banking field (Bourdieu, 1976, 1980, 1992). The personal experience of one of the co-authors (as the former chief financial officer of a closely-held bank) provides us with such rich insights 
into how the bank chairman, senior bank officials, central bank and clients face each other, take alternative positions and dispositions and also exercise their agencies based on their ownership of capital and power.

\section{The banking field (privately owned banks) in Sri Lanka}

This section focuses on the macro issue of mapping the field (as Bourdieu's methodology does) and answer to the questions such as what is the dominant and what is the dominated in this field,; what are the key capitals mobilised in that dominance and how does this field relate to key fields of power. It further reveals the "naturalized" (taken-for-granted) practices in the bank lending field in Sri Lanka.

\section{Rational accounting and credit management structure}

Rational accounting and credit practice protocols in privately owned banks in Sri Lanka are quite similar to any other mainstream banking field in the world. These banks are required adopt rational bank lending checklists such as the 5Cs (character, capacity, capital, collateral and conditions) and also stipulate the judgment systems and credit ratings, e.g., through external credit rating agencies and/or by using internal risk-scoring models. These numerical expressions, based on the level analysis of a person's credit files, represent the creditworthiness of the loan applicant. An applicant's credit score is primarily based on this credit report information sourced either from external credit agencies or from internal risk-scoring models. By doing so, the banks access and minimize the risk of credit facilities extended to their clients. For business credit, in addition to basic credit checklists, the banks are supposed to conduct a quantitative assessment and evaluate the business credit applicants' enterprise performances. This is analyzed mainly through their financial accounts, in particular, through the accounting ratios such as leverage, profitability and liquidity ratios and also balance sheet 
information. The banks also use qualitative factors in their credit evaluation, for example operating experience, management expertise, and quality of assets. Overall, the credit approval decision is made on the basis of both qualitative and quantitative feasibility assessments (of an applicant's business entity). The privately owned banks in Sri Lanka follow a credit policy manual (CPM) to control their lending-related activities. The CPM provides the necessary guidelines to balance compliance with regulatory requirements and profitability. In addition to the CPM, the circulars issued by the respective banks ensure the additional requirements for project appraisals to monitoring of individual accounts and recoveries and write-offs of badly performing accounts. These circulars and suchlike also provide instructions to the bank staff regarding the management of concessionary credit schemes. These guideline documents are very rich in detail and even consist of appropriate checklists and templates for rational credit approval (e.g., the application of the five Cs and conditions for the quantitative and qualitative assessment of loan applications).

\section{Key capitals and domination}

Because of the private economic ownership (economic capital) and the presence of family members and their allies in the director boards, the Chairpersons enjoy dominant power positions within these privately owned banks. One such example is the Soft Bank (case study of the paper). The Soft Group had more than 10,000 employees, over US\$80 million in net assets and US\$2 billion in total assets in 2004. The Soft Bank, which was the banking arm of the Soft Group, accounted for almost 50 per cent of the asset base and one-third of the workforce of the group. The Soft Bank had obtained special approval from the Central Bank Sri Lanka for direct holding of 18 per cent of its equity by the Soft Group. But, Soft Bank had more than 50 per cent of its ownership with the chairman, his wife and a few companies of the group, through indirect holdings and "Employee Share Ownership Schemes" (ESOS) (5 per cent of shares), which were allowed by the 
Banking Act. Using his financial strengths, the present Chairman exploited the concept of ESOS to acquire the control power over the fellow shareholders of Soft Bank. He lent money to his most loyal employees who patronized himself (some were their relatives and friends) at a concessionary rate of interest to purchase their own shares to create six separate ESOS trusts and, each trust acquiring 4.99 per cent of ownership of Soft Bank. This transferred a total of 29.9 per cent of indirect ownership and control to the Chairman. In a similar way, most privately owned banks in the country are owned by groups of companies acting in concert but camouflaged under the veil of incorporation using their subsidiaries to own 4.9 per cent of a particular bank. In addition to this, the bank owners also possess symbolic capital through the resources available on the basis of honour, prestige and recognition, and this signifies the value that they hold within Sri Lankan society, mainly because of their elite backgrounds and the nationally accepted business icon images. For example, one of the national-level universities in Sri Lanka awarded the Chairperson of the Soft Group, Mr. Perera, a Doctorate in 1995 for his contribution towards the business development of the country. A leading business magazine named him Personality of the Year 1995. Because of these substantial and accumulated economic and symbolic capitals, the chairpersons of privately owned banks are often seen allocating their time to personally interfere with and handle customer complaints, the plight of potential customers and even requests from the general public. Here, they exhibit their superior economic and symbolic power to their employees (particularly the bank managers), to manifest themselves as saviours to their customers. In the case of Soft Bank, its Chairman even allowed customers to confront bank managers openly, causing embarrassment to such employed officers.

On the other hand, the managers of privately owned banks, because of their nonfinancial social assets that promote social mobility beyond economic means (e.g. their superior educational backgrounds, embodied knowledge (of banking theory and practice) and education in elite schools) hold enormous cultural capital. 
Then, on the basis of their intellectual honour as financial experts, professional status as leading bankers, professional work style and recognition, they also own symbolic capital for themselves within the privately owned banking field. Furthermore, these leading business people (both owners and senior managers) enjoy huge social capital due to their networks of relationships among people who live and work in Sri Lanka society, enabling them to carry out their personal and business lives effectively. For example, when Mr. Perera (Soft-Bank Chairperson) met with an accident and was admitted to hospital in early 1996, he was visited there by the most venerable priests in Sri Lanka (this is an honour in Sri Lankan society), who prayed for him. The bank owners, highly educated senior bank officials and also large-scale bank clients who belong to Englishspeaking, upper social classes (the elite) of society maintain cartels using social networks such as Old Boys' Associations, and Rotary and Lions Clubs. Through these social networks these individual members accumulate social capital over others in the field and, as a consequence, the financiers (lenders) and borrowers appear to illustrate these differences in the vast gaps within social capital. Indeed, there is a possible inequality of power and domination in the Sri Lankan credit business environment to be explored further in the cases. Finally, political capital also plays a dominant role in the privately owned banking field. It is very common in Sri Lanka for Members of Parliament (MPs) to issue letters requesting (and forcing) senior officers of various institutions to accommodate the interests of their (the politicians') supporters.

\section{Doxa and the dominated}

The low-income customers in the privately owned banking field have internalised some of the logic of these practices as second nature. These dominant practices have been naturalised and appeared as basic and common ways of obtaining the personal loans. In Sri Lankan culture, people believe that an informal approach is an easy way to get things done quickly. The perception of the general public is 
that one must know someone in the bank concerned to receive a positive response. Even though some of the banks are private, there remains a strong belief and culture (doxa) in the banking field that, to obtain a credit facility, one must have to satisfy the bank officials. It is very common for low-income customers who wish to obtain credit facilities from the banks to deliver bulky hampers to the officers and/or branch managers of the banks.

The use of consumer credit is a luxury for the majority of the dominated poor in Sri Lanka. Although 60 per cent of the banking sector is administered by stateowned banks, dominated (poor) credit seekers still prefer to use privately owned banks because of these banks' flexibility in applying credit rules. Branch managers of privately owned banks normally enjoy higher credit approval authority limits and power than do those of state-owned banks. Therefore, a patronage relationship between the customers and bank managers (and owners) as the mean to assess credit is a widely accepted feature (doxa) of Sri Lankan banking culture in all banks, irrespective of ownership type. On the other hand, the bank staff, including top-management-level officers, always appeared to be loyal (and patronised by) to the chairpersons of their respective banks because of their belief that the chairpersons know the trade better than they do (and believe them to be pundits) and in some cases, for the purpose of possible promotion, accepted the Chairpersons' decisions without any questioning. For example, in Soft Bank, most of the bank's support services, such as accounting, catering, security and printing were carried out by sister companies in the group. Therefore, the Soft Bank staff, including the top management officers, always appeared to be loyal and they accepted the Chairman's decisions unreservedly. This common and prevalent practice in the privatelyowned banking field created a collective misconception between the bank staff and mode of domination by the bank owners because of the shared misrecognition and belief (doxa) by both the dominated and the dominating. This collective deception is embedded in a collective habitus among most of the staff in the privately owned bank lending 
field. In Sri Lanka, according to Jayasundara-Smits (2010), patronage seems to have found renewed energy in cultural and everyday life. She explains that one of the reasons for this continued trend in renewed patronage ties is the persistent reliance of various social forces on traditional patronage relationships. More relevant to this study, with regard to patronage, Jayasundara-Smits (2010, p. 7) points out that "these relationships have not always contributed to significant improvements in the overall quality of life of the majority that continued to live under unfavourable structural and cultural conditions in the periphery". However, this order and restraint have been established and maintained through indirect cultural mechanisms as opposed to direct, coercive control. This historically developed symbolic violence practice (or tradition) nurtures a conducive environment for decision-makers to enhance their socio-economic power base and establish their dominance over the dominated classes in the society.

\section{Soft Bank's accounting and bank lending practice}

This section explores the micro level practices and, in particular, how individual actors with a given habitus behave and follow strategies which create and reinforce discrimination. The analysis uses Bourdieu's notions of doxa, symbolic violence and domination to argue more clearly how accounting plays a role in the symbolic process to create and sustain discrimination. Based on one of the author's recollection of accounts and insights (during the period 1994-2004) from the participants' interviews (auto-ethnography), two case studies (Tony Group and Superclean Services) from Soft Bank (one of the leading privately owned banks in Sri Lanka) have been developed for subsequent analysis although at the time of occurrence no intention of publishing these details of events was conceived (Silverman, 1997; Yin, 2003). The authors believe that these two highprofile cases represent and mirror how individuals within a given habitus deploy rational accounting systems at micro levels to translate discriminatory bank lending policies into practice and thereby sustain discrimination. 


\section{Patronising the chairman}

In the case study of the Tony Group, its owner (Mr. Tony) uses a patronage habitus to influence Soft Bank Chairman (Mr. Perera) and obtain US\$1.5 million loan to finance input materials for his loss-making business. He used his personal connections, networks (social capital) to please the Soft Bank Chairman. As previously mentioned, the Soft Bank Chairman is embedded in extensive social networks of friends, business partners and high profile customers, groups within which he can discuss business and personal life ambitions, such as becoming a national-level leader.

The Tony Group is one of the largest garment manufacturers in Sri Lanka, producing a significant share of the country's exports and employing over 25,000 workers. Mr. Tony (the owner of Tony Group) had won several awards for his achievements. He had maintained a very close working relationship with a past Sri Lankan president and enjoyed state patronage, including credit facilities from state-owned banks, to expand his business in line with government policy at the time. Mr. Tony had become a powerful businessman and gained a prominent position in an elite circle in Sri Lankan social networks. He was building his socio-economic power not only within the garment manufacturing industry, but also more generally. But, with a change of government and political regime in the country, he had started facing problems. He had complained that he was not allocated an adequate quota to allow his factories to work at full capacity. This financial situation had forced him to apply for a credit facility from the Soft Bank. Mr. Tony approached the Soft Bank Chairman while he was conducting one of the bank's review meetings and requested an immediate appointment to discuss his urgent matter. The response of the Soft Bank Chairman was to arrange a quick appointment/meeting, showing respect for Mr. Tony's reputation as a fellow business tycoon. 
However, Mr. Tony had made a previous application for credit facilities from Soft Bank, but had been rejected by the credit officer because of an official credit-default investigation report. Mr. Tony and the Soft Bank Chairman (Mr. Perera) knew each other as leading businesspersons working in different fields in Sri Lanka. Therefore, the Soft Bank Chairman's approach to Mr. Tony's new application for the credit facilities was very casual; thus all previous negative accounting figures were ignored and the formal credit approval rules were bypassed. Mr. Tony defended his poor accounting figures and financial performances by saying that his group was running with a negative cash flow only because of the under-utilisation of assets. He was in the midst of a crisis, and stated that he had no money to pay the salary bill even for that month. The best employees were leaving the group and he said he had no option but to agree to the foreclosure that had been suggested by the existing banks. He also pointed out that the new owners of his business would not be able to maintain the same rapport with the international buyers and that the whole episode would result in tragedy, making 25,000 workers redundant. He pleaded with the Soft Bank Chairman to bail him out, assuring him that a Soft Bank credit line would rejuvenate the whole group and that future cash flows would be very healthy with incoming orders expected. He also requested a Letter of Credit (LC) facility to import the necessary fabrics.

At the request of the Soft Bank Chairman (Mr. Perera), Mr. Tony explained his cash-flow situation and borrowing position. The total borrowings of the Tony Group were more than US\$20 million. These comprised US\$5 million from the Bank of Lanka, US\$5 million from SET Bank, US\$2 million from HAT Bank and a syndicated loan of US\$8 million from all three banks. He had borrowed from three private banks and the Bank of Lanka, the largest state-owned bank in Sri Lanka, which had structured a syndicated loan as well. The monthly commitment for servicing these loans was US\$0.7 million. Due to non-servicing 
of interest, almost all the banks had classified the Tony Group as a defaulter and had reported this to the Credit Information Bureau (CIB), which is the central monitoring authority. When evaluating the creditworthiness of a client, the first thing a credit officer has to do is to call for a CIB report on the client. Mr. Tony had applied for a facility from the Soft Bank a week previously, and the team leader of the Corporate Credit Division had declined it on the basis of the CIB report. Mr. Tony was ingratiatingly convincing; he explained with humble politeness how the senior officers of the Soft Bank had come to reject his proposal and, in advance, he praised the Chairman for his visionary leadership and patriotic attitudes. The Chairman (Mr. Perera) expressed his grief about the situation and blamed the politicians, regulators and bankers for not identifying the needs of the country.

The Soft Bank Chairman said that bankers were guided by some rules called banking practices, which can ruin potential enterprises. According to the recollection of the observer, Soft Bank Chairman had said:

...they will never think beyond that cage of banking practices. Even our state policies do not have provisions to support people like you [Mr. Tony]. Now, you have generated 25,000 jobs. If they lose their jobs and you lose your business, the cost to the economy will be much more in the long run.

Then, in a discouraged tone, Chairman had said:

I don't know when these people will learn these things.

Mr. Tony seconded this and in particular supported the views of Soft Bank Chairman and started criticizing the prevailing systems. Then Mr. Tony and the Soft Bank Chairman, according to the observer's best recollection, engaged in the following conversation:

Chairman: "Tell me Mr. Tony, how much do you want? And what is the collateral you can offer?" 
Mr. Tony: "Sir, all my assets have been taken by the existing banks. I can give my personal guarantee and the secondary mortgage of the assets, which have already been mortgaged to the other banks, and Chairman Sir, believe me and I will not let you down."

Chairman: "Your house?"

Mr. Tony: “That's in my wife's name and I am sorry sir, I can't draw her into this, she will eat me."

Chairman: "Can you give your wife's personal guarantee?"

Mr. Tony: "I am very sorry sir, but do not worry I will never let you down and I will pay every cent due to your bank on time, and I am not going to deal with any of those other banks in the future, my one and only bank is your bank for the rest of my life."

Chairman: "Ok, tell me your requirement, have you got a good accountant? Do you have the cash-flow projections?"

Mr. Tony: "Yes sir, our cash flow is always positive but not adequate to service the loans because of production hiccups and not running our factories at their full capacity. If you help we can have enough orders to fill the factories to perform at full capacity. We will then have an initial cash surplus of US\$1 million and that would grow to US\$1.5 million in three months' time. To do this I need an advance of US\$2.5 million to pay my salary bill and other statutory dues. And I need an LC facility of US\$1.5 million to finance input materials for uninterrupted production.”

The financial controller then tabled a monthly cash-flow projection and explained it, and the Soft Bank Chairman looked convinced.

Chairman: "Is that all you need? Tell me right now; you will not be assisted under the normal banking practices by our credit officers in the bank." 
Mr. Tony: "Yes, that's what I wanted your Honour. I do not need a cent more than what is necessary."

Mr. Tony invited the Chairman to chair his board: "Why don't you come and chair our Board meetings as well?"

The Chairman thanked him for the invitation and said: "I don't want to interfere with your business, you are the best person to manage your business, but you can give us good publicity."

Mr. Tony: “Of course, sir,” Mr. Tony readily agreed.

The above story demonstrates a situation where a borrower exercised the "patronage" habitus and also used his social capital to influence the credit decision-makers; on the other hand the Soft Bank Chairman, because of his pundit self-image habitus (his omniscient belief) used his symbolic capital, bypassing all the negative accounting information produced by his and Mr. Tony's accountants, to convince the Soft Bank board of directors to ratify his casual and biased decisions. Whilst the mastery of technical competencies is generally associated with the professional accountants (or financial controllers), the above case study indicates that the knowledge about basic/elementary accounting practice and superficial regard of the accounting controls and figures (by the Soft Bank chairman) still play a central and unshakable role in the Soft Bank Chairman's habitus of a pundit self-image (that of "knowing everything"). Indeed, accounting practices here provided a convenient and acceptable officializing strategy and symbolic power to Soft Bank Chairman (Mr. Perera) when he was legitimising his interests within lending decisions. Moreover, the Soft Bank Chairman also managed to reinforce his own social capital. Mr. Tony (loan applicant) and the Soft Bank Chairman both belonged to the same social class and knew each other as leading businesspersons in Sri Lanka. They both were well known and powerful and had been prominent in the elite circles and social networks in Sri Lanka. The personal connection with the owner was the influential factor in creating this situation of bias and favoritism, and the making 
of a discriminatory loan approval decision. In this context, specifically, accounting facilitated a form of symbolic violence and is implicated in the credit approval mechanisms by which powerful actors, such as Soft Bank Chairman, consolidated their influence and secured their position.

\section{Chairman's Pundit omniscient self-image}

This section further analyses the habitus of the Soft Bank Chairman which is comprised of durable and transposable dispositions, and draws attention to the enduring logic and functionality of discriminatory use of accounting practices. The career habitus of an individual can be defined by the dispositions which tend to be automatically actualized within the field of career (Krais, 1988). The actualization of such dispositions depends mainly on contextual opportunities but also a socio-psychological portrait of each individual in a work context. In this perspective, the Soft Bank Chairman (Mr. Perera) drew upon his position at the Soft Bank (with accumulated economic capital), social and symbolic capital which he had built up by being in the business over 40 years. In particular, he laid claim to his designation as Chairman in his group of companies and as a public figure promoting national economic development. He then also leveraged this organizational location to deal almost exclusively with subordinates and customers through his elite contacts, such as upper-class family background, Rotary and Lions club memberships. By using this form of social capital, he has been enabled to solidify his position and to place his personal stamp on its realiszation. The Soft Bank Chairperson established himself as a charismatic leader and created a patriotic and charismatic image in public. Symbolically he appeared to others as someone who seems to know without having learned those behaviours and common references that distinguish a leader. In Mr. Perera's (Chairperson's) persona, this is attributable to his speaking English, his public school education and the way such an elite family acquired cultural and symbolic capital that translated into an omniscient habitus then accepted by the fellow staff 
members of the Soft Bank, members of his own social class and clubs and in wider society (his portrait as a national figure and business icon). In addition, his official position in the organization and the group as the Chairperson (and his ownership of economic capital), gave him a leadership right to impose a "social vision of the world". This created potential for symbolic violence within Mr. Perera's leadership as his followers believed he was a charismatic figure, even though he had violated many basic principles of a good leader in his managerial decision-making, for example, through breaking all the accounting controls and credit evaluation rules, over-ruling his fellow staff's credit management decisions (often without consultation), making biased credit approval decisions and promoting favouritism.

To elaborate further, Soft Bank Chairman (Mr. Perera) was seen to consistently make reference to, and activate, some very elementary forms of accounting practices, summed up by what he described as balance sheet management. This encompassed having a very good practical and situated knowledge of rates of profitability, cash flows, and the relationship between debt and equity and so on, both generally and in the context of Soft Bank and his group of companies. These practices comprised a very important part of the omniscient habitus of Mr. Perera in his capacity as the Chairman. Thus his incorporation of these basic accounting practices provided him with a background for understanding and instigating actions across a range of different situations. The case evidence shows that these practices had served him well in the past, over a long career, permitting him to function in a variety of different work contexts, e.g., economic sectors, industries and with clients.

The above characteristics of Soft Bank Chairman (Mr. Perera) were largely evident in the Tony Group case study. Thus, the Chairperson had quickly reached an assessment of Mr. Tony's integrity, and the risk and return of the credit involved, and he instantly granted US\$4 million. The Chairperson was not 
anticipating any personal gratification but showed some sympathy for the workforce of the Tony Group, who were without wages and facing redundancy because of the foreclosure of factories that had been called by the other banks to recover their debts. By doing so, Mr. Perera managed to strengthen his public figure image and symbolic power. The following day, the business page of a leading newspaper carried an article entitled, "Soft Bank rescued Tony Group". The news spread fast and Mr. Tony announced that Mr. Perera had helped him. He issued a special circular among the Tony Group employees, telling them they had to all do their banking with the Soft Bank, explaining that the Soft Bank was a truly kind bank, while criticizing all other banks for pushing him to sell the factories. The Chairperson was jubilant about the publicity and copies of the clipping of the news item circulated among the board members at the next board meeting. He assured the board that he would bring more and more business and expressed his regrets, saying that he should have involved himself more in the day-to-day activities of the bank earlier (referring to the accounting controls and credit decisions). The Chairperson requested that Mr. Tony give the maximum publicity for this rescue operation in reciprocation, and rejected the Chairmanship of the Tony group which was offered by Mr. Tony. Mr. Tony, exercising his patronising habitus, duly provided maximum publicity to Soft Bank Chairman. However, despite all these dramatic publicity moves by Mr. Tony, later the Tony group's business collapsed, the Soft Bank loan was classified as a bad debt and provisions were made to comply with the regulatory requirements. The interest loss was reported to be around US\$0.3 million and the capital loss was also significant. This case evidence reflects how the Soft Bank Chairman mobiliszed the elementary accounting practices embedded in his pundit self-image to create a basis for a relational distinction. Thus he was able to perform a key lending decision in a discriminatory way that was distinguished from the rational mechanisms set up by his accomplishments from those of other top managers and financial controllers in Soft Bank. Interestingly, none of these top managers or financial controllers sought to distinguish their position by challenging the views 
of the Soft Bank Chairman. The reason for that was that the Soft Bank Chairman had mobilized significant symbolic and cultural capital to justify and implement his decisions. The accounting played a substantial role in this symbolic process to create and sustain discrimination.

In a different perspective, Soft Bank Chairman's vision became bound up in the Soft Bank credit approval culture where he believed Soft Bank credit policy should symbolize commitment to Sri Lankan national economic development (e.g., Mr. Tony's loan-approval case). The team leader of the Soft Bank's corporate credit division indicated that the Mr. Tony's application was declined on the basis of the CIB report. But, over-ruling the corporate credit division decision, the Chairperson exhibited favouritism and instantly granted US\$4 million to Mr. Tony. In this recommendation, the staff of the corporate credit division had accepted the fact that they were not free to make credit appraisals, but were expected to anticipate what would be acceptable to the Chairman's visionary, patriotic and upper-class tastes. In other words, they misconstrued their role as being unquestioning of authority and instigated a situation of symbolic violence. Thus the Soft Bank credit culture served as a way of securing $\mathrm{Mr}$. Perera's legacy, of legitimizing his own charismatic authority and ensuring its continuation into the future as objectified symbolic violence both within the Soft Bank and more widely, within the country. By doing so, he might have expected that this could be converted into a form of cultural capital with a future top post in the government. This connects with the fact that he maintained close connections with powerful politicians, especially with the former government of the country. The Chairperson often strode up and down while speaking from the heart to his Soft Bank staff and clients about his vision for the country, and his belief in the Soft Bank's contribution to national economic development. This patriotic rhetoric is central to the process of creating an emotional "identification" with the Soft Bank chairman, as it communicates a feeling of oneness between himself (as a charismatic leader) and his followers (bank staff, clients and 
society). This misrecognition of power relations as personal relations embodies a practice of symbolic violence.

The Financial Controllers who participated in the credit evaluation decisions of Soft Bank then were seen to accept and endorse the legitimacy of the dominant values and classification schema associated with it, as imposed by the most powerful, in this case the Soft Bank Chairman. Thus, the Soft Bank Chairman was not content to allow others in the accounting and finance function to get their work done as he was always involved in detailed intervention and interference; he was keen to be informed of the progress of projects and impending difficulties; he was more likely to manage using talk rather than written forms of communication; he was predisposed to the perquisites of high office; he actively sought to cultivate the influence of symbolic power, bringing a high degree of political acuity to his position; and, he was predisposed to question his own staff and initiate favouritism to his clients through the implementation of discriminatory accounting information. One of the other potential reasons for the above-stated silence of bank managers was their desire for promotion into the senior positions of the bank and a perception of the Chairman as the gatekeeper to such a future that overrode any dissatisfaction with the established credit management climate. In pursuing their own goals then, the bank managers engaged in social practices that contributed to the existing structure and helped to reproduce it. In this respect, the complicity of the dominated actors (bank managers) becomes obvious as an essential element within symbolic violence that can only be exerted on a person predisposed, through the habitus, to feel it.

\section{Exchanging personal favours}

Some Soft Bank clients used the habitus of exchanging personal favours to obtain credit facilities. They experienced a dominated class situation (primarily formed by financial constraints and poor social capital prevailing in their socialisation) 
largely of an inert disposition. One such example was how a Mr. Silva (owner of Superclean services) managed his relationships with the Soft Bank branch managers. Mr. Silva, who came from a Colombo suburb, was in his late forties. He took advantage of an early retirement plan from his employer Timber Corporation, a semi-governmental corporation, and decided to start a business. In 1991, he formed a sole proprietorship, Superclean Services, to provide janitorial services on a commercial basis. His first client was the Dehiwela branch of the Soft Bank, which was the first branch of the Soft Bank. His service proved to be most satisfactory so he was contracted for all the janitorial services for the bank. As the Soft Bank expanded its branch network rapidly, Superclean's business, as the sole janitorial service provider, also boomed. Mr. Fernando, the manager of Dehiwela branch, handled the Superclean account systematically, financing its initial capital investment requirements to serve the newly opened branches. The recovery process was streamlined by directing the payments from the Soft Bank to the loan account of Superclean. Superclean was exceptionally good at meeting the requirements of finishing up at branch openings, mostly at short notice, and sometimes at concurrent branch openings. Furthermore, Mr. Silva supplied all these services free of charge for the opening day polish-ups, strengthening the firm's relationship with the bank.

As the business was small in scale, Mr. Silva was not known to the top management of the Soft Bank. Mr. Silva had accumulated considerable assets in his business and always had substantial payments due from the bank, against which he had facilities including an overdraft. His ambition was to provide services to big institutions such as the Parliament, airport and embassies. Mr. Silva was trying to accumulate social capital through networking because he thought that would help him to promote his business growth. For that purpose he invested more in business promotions and subsequently created a liquidity problem. The branch manager at Dehiwala Branch, Mr. Fernando, was worried about continuing requests by Mr. Silva for additional credit facilities and/or 
overdue loans. However, Mr. Silva claimed that he had overdue money from the bank. He was unable to prove his claim because of his limited accounting knowledge and expertise. Mr. Silva used his habitus of personal favours, such as polishing the home floors of bank officers who did him even the slightest favour. Mr. Silva, who operated in a small, city-based company, also used his habitus of style (the personal stamp) to gain favour to get access to resources. Then the personal favours from Mr. Silva to the bank officers had become an established practice. However, his inability to cope with the continuous requests made by down-the-line staff (in addition to the managers) caused irritation within staff circles. Some of the bank officials who were not rewarded by Mr. Silva made a point of complaining that the Superclean services were not up to standard. In response, the Soft Bank branch managers started to cut payments for the slightest lapse or error made by Superclean staff. Moreover, branch managers sought permission from the CEO of the bank to allow them to be responsible for their own janitorial needs, and took away the Superclean employees by hiring them to their branches on a contract basis.

Meanwhile, Mr. Nath, who was in charge of janitorial services at ABC Ltd, an established large company in the same business as Superclean, approached the Soft Bank through the Personal Assistant (PA) to the CEO. The PA, who was an old classmate of Mr. Nath (in Nath's social network), was placed fully in charge of the bank's janitorial services and started to divide the branch janitorial work between the two contenders, ABC and Superclean. However, it was still expected that Superclean would attend to the opening day's work for new branches, which was offered free, and thereafter it was the PA who decided to give which branch to whom. Simultaneously, Mr. Fernando, manager of the Dehiwela Branch, was promoted and transferred to the head office and the credit officer of the Dehiwela Branch, where Mr. Silva had his account, became a powerful figure in the branch. The credit officer, who was not on very good terms with Mr. Silva as a result of a misunderstanding (caused by Mr. Silva's refusal to offer a particular personal 
favour), started treating the Superclean account with discipline in the strictest sense, ignoring delays in receiving bank payments thereto and thus depriving Mr. Silva of business expansion. The intervention in janitorial business by the PA (to the Soft Bank CEO) had further aggravated the issue. Mr. Silva experienced a severe liquidity crunch and gradually lost business because the Soft Bank did not issue any performance bonds for Superclean to canvass new clients. It also returned all cheques if funds were lacking and no arrangements had been made. Finally, the Soft Bank did not extend the advances against payments from the bank and did not allow withdrawals from his account until overdues were cleared (despite payments to him from the bank having been overdue for months).

However, it was later revealed that the Soft Bank Dehiwela branch had overrecovered Superclean's loan (charged) interest, substantially enough to recover half the term loan. Superclean, which was too small to afford qualified or experienced accountants, was totally reliant on the bank statements to assess their daily finances. Mr. Silva's accounting literacy was not sufficient to understand his personal accounting reports and statements. Soft Bank classified the Superclean account as non-performing and transferred the file to the recoveries department for closely monitored recovery action, failing which the Soft Bank could serve a Letter of Demand to proceed towards legal action. After careful examination of the account, and realising that the Soft Bank had overcharged interest and pushed the client to the non-performing condition, the recoveries manager comprehended Mr. Silva's plight in all aspects, i.e., the overcharging of interest; the non-recovery of capital whilst funds were actually available (due from the bank) causing a loss situation to the client; and the deprivation of business expansion, which was, arguably, criminal negligence in the banking sense. In contrast to the Tony Group owner, Mr. Silva lacked social capital and also lacked proper accounting knowledge and literacy, and was neglected by the credit decision makers of Soft Bank. This case brought discriminatory actions to the surface and underlined the increasing importance of social capital, such as 
social networks, group memberships and the connections needed to access credit from the privately owned banks in countries like Sri Lanka.

Moreover, the case evidence strongly suggests that banks which embed the credit decisions with the borrowers in their social networks (those with social capital) offer favourable decisions on loans. On the other hand, credit applicants were more unlikely to get bank credit if their social capital (the network of ties with the Chairman and senior bank staff) provided them with unequal or arm's length ties. The authors contend that the more commercial transactions are embedded in social attachments, the more there are expectations of trust governing exchanges. These unequal, or arm's length ties, and weak social capital forced the Soft Bank loan applicants to disposition themselves and practice actions such as exchanging personal favours, to get closer to the branch managers. In particular, exchanging personal favours filled the gaps in arm's-length ties and provided a platform for the collaboration, resulting in different economic consequences (as the case evidence demonstrated). This habitus of personal favours from Mr. Silva turned into a taken-for-granted and unquestioned truth (doxa) among the Soft Bank staff and formed a state of symbolic violence, as this collective deception practised on the borrower by the bank staff created misrecognition between dominated and dominating. This correlates with the evidence that bank staff considered Mr. Silva had a formal obligation to offer them personal favours. In fact, some of the bank officials complained about Mr. Silva (for the quality of Superclean Services' work) to higher authorities, simply because he was unable to serve down-the-line bank staff. This misrecognition of power relations as obligation from the borrower's perspective is one of the properties of symbolic violence.

\section{Bank managers' opportunistic behaviour}

Usually, there can be two ways to form a career-related habitus: through accumulation of educational, economic and social capital within the family of 
origin and through personality traits and social and strategic behavioral dispositions for social contacts (Krais, 1988). The Soft Bank managers used the latter and practiced an opportunistic behavior habitus for their career advancements. When doing so, they produced discriminatory accounting practices and strategically violated the basic banking lending procedures of the Soft Bank. For example, in the case of Superclean's owner Mr. Silva, because of the continuous harassments by the Soft Bank' recoveries manager at the time, had lost all his credibility and business integrity and was unable to pursue tender bids without performance bonds. The only business that Superclean had at the time was supplying cleaning services to a few branches in the civil war areas of the country (the North and East) where ABC (the competitor of the cleaning business) was reluctant to work. At one point, the recoveries manager called for explanations by the Soft Bank hierarchy about the overcharged interest from the new branch manager of the Dehiwela branch. A senior bank officer indicated that this action (the call for explanation) probably might not have been intended to take action against the errant staff but perhaps to build up a case and find an avenue to help a victim of errant bank action. The recoveries manager, comprehending Mr. Silva's plight, extended several bank facilities which were outside the normal credit rules. The recoveries manager blamed the branch staff for Mr. Silva's situation but, rather than reporting the misbehaviour to management, used his awareness of it to intimidate the branch staff. The recoveries manager used the reduction shown in the bad loans he handled as a performance measure to control and influence branch staff. If the recoveries manager could transfer restructured bad loans back to branches as performing loans, that process would have enhanced his own performance (on paper), for which he would have been rewarded. But the recoveries manager did not have the necessary authority to approve new credit facilities. He abused his authority and had an advantage, as the branch staff were under obligation to him for his failure to report their lapse. Though the recoveries manager's performance earned him promotion and top management encouragement, as soon as his approval of credit 
beyond the limits of his authority was discovered, he was dismissed from his position.

The new chief manager, recovery, a retired orthodox banker, applied the established credit rules strictly. He stopped all the facilities extended to Superclean by the recoveries manager and requested Mr. Silva to settle existing outstanding debt immediately before he would consider further facilities. The new chief manager, recovery, through practicing opportunistic behaviour also tried to impress the top management with his good work. He contemplated serving a letter of demand threatening legal action against Mr. Silva and his house, which was mortgaged to the Soft Bank. Mr. Silva, as advised by people who were aware of the best way to approach the Chairperson (Mr. Perera), had searched for avenues to make such an approach. However, unlike Mr. Tony, Mr. Silva did not belong to the Soft bank Chairperson's social class or social network. Research participants were of the view that, if Mr. Silva had ensured sufficient social contacts to approach the Chairperson, he could have obtained the necessary facilities, and the recoveries manager would have been rewarded with another promotion instead of losing his job. The career-related habitus of obtaining professional banking knowledge and accounting qualifications, and the expression of that ability in financial accounting and credit management tasks had created a unique knowledge power situation amongst the bank staff over their loan applicants (clients). In this respect, professional banking knowledge and qualifications was a form of institutionalised cultural capital, symbolic capital (or both), and was perceived by the bank staff (especially the branch managers) as transferable to economic capital. The bank managers gained recognition at the institutional level, most commonly because of their academic credentials, accounting and banking qualifications and experience/knowledge. Therefore, most of them tried to individually compare their ownership of cultural capital against that of others. Consequently, the apparent shortage of such capital encouraged some managers to practice the career habitus of continually 
manoeuvring to improve their performance, organizational position and status in relation to each other. They also attempted to convert their cultural capital into economic capital by demonstrating their personal value (through superior performance against others) to the Chairperson. This promoted a culture of opportunistic behaviour amongst the Soft Bank staff. For example, the junior recoveries manager in the Superclean case study called for explanations about the overcharged interest from the branch manager. He then used the reduction shown in the bad loans he handled as the performance measure to branch staff and also went beyond his authority to approve extended facilities to Superclean, outside the normal credit rules of Soft Bank. Consequently, the chief manager, recovery, tried to impress top management by exposing the wrongdoings of his junior manager. On the basis of misused authority, the junior recoveries manager was then dismissed from his position. This story reflects how the bank staff who were short of the necessary cultural capital to gain higher positions within the Soft Bank, exercised exploitative tactics and encouraged opportunistic behaviour amongst their own community. On the other hand, because of the Soft Bank Chairman's "knowing everything" and bank managers' "opportunistic behaviour", the financial controllers of Soft Bank were forced to practice the most elementary of the practising accountants' competencies, even though their mastery of technical competencies is generally associated with the development of novice accounting practitioners. The case evidence indicates that such elementary practices dominated the credit practices of Soft Bank and played a central and abiding role in the general career habitus of expert exponents of the accounting craft.

\section{Conclusion}

The paper analysed the links between accounting and discrimination, and illustrated how accounting techniques help to translate discriminatory bank lending policies into practice, and create and reinforce discrimination. In order to 
address this situation, it has presented an empirical study, based on data gathered through an analytical auto-ethnography (during the period 1994-2004) coupled with follow-up interviews and reiterated analyses within a within a privately owned Sri Lankan bank, drawing out the conditions that allowed two stories of accounting and discriminatory bank lending to be established. It also used a theoretical framework based on Bourdieu's concepts of field, capital, habitus, doxa, symbolic violence and domination. Such concepts are applicable in explaining and arguing more clearly how accounting plays a key role in a symbolic process to create and sustain discrimination in the bank lending field.

Previous studies have highlighted a nexus between the accounting and discrimination. For instance, Fleischman and Tyson (2000) analysed the interface of race and accounting, Fleischman and Tyson (2004) discussed accounting and slavery, and Neu (2000) explained the connection between accounting techniques and reproductive genocide, cultural genocide and ecocide. Moreover, Davie's (2002) research highlighted how the accounting involved in race relations creates and perpetuates differentiatory, racialised identities of social and economic relations. However, none of these studies provides any understanding of how accounting creates and sustain discrimination in the privately owned bank lending field. This paper thus seeks to fill this gap in the literature and shows how, in a bank lending field in which economic, social, cultural and symbolic capital are so dominant, the powerful actors, such as a Chairman and bank managers, use accounting information, tools and accounts to exert symbolic violence. This is accepted by both those who exert it (a Chairman, some bank managers) and those who are subject to it (bank customers without social capital and power, some bank staff). They use manipulated accounting to create disproportionate power structures and make bank lending decisions perceived as objective. The paper thus demonstrated that accounting information, tools and accounts themselves were deliberately "smoothed" to reinforce unequal positions of power and shape the interests of the dominant (e.g., powerful bank owners and 
some managers). As a result, the dominated actors, rather than resisting, exercised their agency through habitus (exchanging favours, patronage on the part of the chairman, and opportunistic behaviours) in order to influence the dominant actors to make advantageous decisions and ontologically secure their own positions in the organization. One unique feature though, was the undit (or omniscient belief) habitus of the Chairman. This has contributed to further reproduce accounting-led discrimination and also created a situation exhibiting symbolic power and violence. Thus, the Chairman, through use of basic/elementary levels of accounting knowledge has justified his discriminatory bank lending decisions in favour of his clients who practiced business within the habitus of patronage. Finally, the paper reveals the ways the dominant actors (for example, a Chairman) relate accounting controls and information to common sense discourses (for example, visionary leadership and patriotic attitudes) and conceal rational organizational practices (for example, rational accounting and credit control systems) to create and legitimize disproportionate symbolic power positions.

The paper broadly expands the accounting research that attempts to understand how forms of accounting emerge from, sustain and modify wider institutional and social practices, such as discrimination. It further demonstrates the accounting's embeddedness on different forms of habitus, such as patronage, omniscient selfbeliefs, exchanging personal favours, and opportunistic behaviour. Besides this, the paper underlines the controversial role of accounting in a powerful symbolic process that recognize, produce and reproduce practical dispositions for day-today work practices.

\section{References}

Anderson, L. (2006) Analytic autoethnography. Journal of Contemporary Ethnography, 35(4), 373-395. 
Bank of England. (1999) Speech by the Governor at the KPMG profitability seminar; Speech given by Edward George, Governor of the Bank of England, 1 1999. March Retrieved from http://www.bankofengland.co.uk/archive/Documents/historicpubs/speech es/ 1999/speech37.pdf

Boltanski, L. \& Chiapello, E. (2005) The new spirit of capitalism. London: Verso [Original edition 1999]. Le nouvel esprit du capitalisme.[The new spirit of capitalism]. Paris, France: Gallimard.

Bourdieu, P. (1976) Les modes de domination. Actes de la Recherche en Sciences Sociales, 2(2), 122-132.

Bourdieu, P. (1977) Sur le pouvoir symbolique. Annales. Histoire, Sciences Sociales, 32(3), 405-411.

Bourdieu, P. (1977) Outline of a theory of practice. Cambridge, UK: Cambridge University Press.

Bourdieu, P. (1980) Le sens pratique, Paris, France: Editions de Minuit.

Bourdieu, P. (1984) Distinction. Cambridge, UK: Polity.

Bourdieu, P. (1986) The production of belief: Contribution to an economy of symbolic goods. In R. Collins (Ed.), Media, culture and society: A critical reader (pp. 131-163). London, UK: Sage Publications.

Bourdieu, P. (1990) The logic of practice. Stanford, CA: Stanford University Press.

Bourdieu, P. (1998) Practical reason: On the theory of action. Cambridge, UK: Polity Press.

Bourdieu, P. (2007) Sketch for a self-analysis. Chicago, IL: The University of Chicago Press.

Bourdieu, P., \& Wacquant, L. J. D. (1992) An invitation to reflexive sociology. Oxford, UK: Polity Press.

Butler, B. (2009) How can structural film expand the language of experimental ethnography? $\mathrm{PhD}$ thesis, University of the Arts, London. 
Cavalluzzo, K., Cavalluzzo, L. and Wolken, J. (2002) "Competition, Small Business Financing, and Discrimination: Evidence From a New Survey," Journal of Business, October, VOL. 75:4, p. 641-680.

Chang, H. (2007) Autoethnography: Raising cultural awareness of self and others. In G. Walford (Ed.), Methodological developments in ethnography. Studies in educational ethnography (Vol. 12, pp. 201-221). Boston, MA: Elsevier.

Davie, S. S. K. (2002)) The policies of accounting, race, and ethnicity: A story of a chiefly-based preferencing, conference paper. Fifth Critical Perspective on Accounting Conference, Baruch College, CUNY. .

Ellis, C. S. (2004) The ethnographic I: A methodological novel about autoethnography. Walnut Creek, CA: Altamira Press.

Ellis, C., Adams, T. E., \& Bochner, A. P. (2011) Autoethnography: an overview. Historical Social Research: 273-290.

Everett, J. (2002) Organizational research and the praxeology of Pierre Bourdieu, Organizational Research Methods, 5(1), 56-80.

Fleischman, R. K., \& Tyson, T. N. (2000) The interface of race and accounting: the case of Hawaiian sugar plantations, 1835-20041920. Accounting History, 5(7), 7-32.

Fleischman, R. K. \& Tyson, T. N. (2004) Accounting in service to racism: monetizing Slave property in the antebellum South. Critical Perspectives on Accounting, 15(3), 376-399.

Ford, J., \& Harding, N. (2008). Fear and loathing in Harrogate or a study of a conference. Organization, 15(2), 233-250.

Ford, J., Harding, N., \& Learmonth, M. (2010) Who is it that would make business schools more critical? Critical reflections on critical management studies. British Journal of Management, 21, 71-81.

Grey, C., \& Sinclair, A. (2006) Writing differently. Organization, 13, 443-453. 
Haber, S. H. (2004) Mexico's experiments with bank privatisation and liberalisation, 1991-2004. Journal of Banking and Finance, 29, 23252353 .

Hopwood, A. G. (1992) Accounting calculation and the shifting sphere of the economic. The European Accounting Review, 1, 125-143.

Humphreys M., \& Learmonth, M. (2010) Public sector management? But we're academics, we don't do that sort of thing! In G. Currie, J. Ford, N. Harding, \& M. Learmonth (Eds.), Making public services management critical (pp. 55-67). New York, NY: Routledge.

Jayasundara-Smits, S. (2010, September). Patronage in Sri Lanka. Paper presented at the Symposium: Promoting social inclusion in South Asia: Policies, pitfalls and analysis of welfare/insecurity regimes. Centre of Development Studies, University of Bath.

Karra, N., \& Phillips, N. (2008) Researching "back home": International management research as autoethnography. Organizational Research Methods, 11(3), 541-561.

Keenoy, T., \& Seijo, G. (2010) Re-imagining e-mail: Academics in the castle. Organization. 17(2), 177-198.

Krais, B. (1988) Der Begiff des Habitus bei Bourdieu und seine Bedeutung für die Bildungstheorie. [The concept of habitus in Bourdieu and its importance in the theory of education]. In B. Dewe, G. Frank, W. \& Huge (Eds.), Der Begiff des Habitus bei Bourdieu und seine Bedeutung für die Bildungstheorie [The concept of habitus in Bourdieu and its importance in the theory of education]. , München: Hueber.

Learmonth, M., \& Humphreys, M. (2012) Autoethnography and academic identity: Glimpsing business school doppelgangers. Organization, 19, 99117.

Madison, D. S. (2006) The dialogic performative in critical ethnography. Text and Performance Quarterly, 26(4), 320-324. 
Malsch, B., Gendron, Y., \& Grazzini, F. (2011) Investigating interdisciplinary translations: The influence of Pierre Bourdieu on accounting literature. Accounting, Auditing \& Accountability Journal, 24(2), 194-228.

Miller, P., \& Napier, C. (1993) Genealogies of calculation, Accounting, Organizations and Society, 18(7/8): 631-647.

Neu, D. (2000) Accounting and accountability relations: Colonisation, genocide and Canada's first nations, Accounting, Auditing \& Accountability Journal, 12(3), 268-288.

Neu, D., Ocampo, E., Graham, C., \& Heincke, M. (2006) Informing technologies and the World Bank. Accounting, Organizations and Society, 31(7), 635662.

Neu, D., \& Taylor, A. (2000) Funding mechanisms, Cost drivers and the distribution of education funds in Alberta, Alberta Journal of Educational Research, 65(3), 214-232.

Pelias, R. J. (2000) The critical life. Communication Education, 49(3), 220-228.

Porter, T. D. (1992) Quantification and the accounting ideal in science. Social Studies in Science, 22, 633-652.

Power, M. (1994) The audit explosion. London, UK: Demos.

Preston, A., Chua, W. F., \& Neu, D. (1997) The diagnosis-related group prospective payment system and the problem of government rationing health care to the elderly. Accounting, Organizations and Society, 22(2), 147-164.

Puxty, A. G. (1986) Social accounting as immanent legitimation: A critique of a technicist ideology. Advances in Public Interest Accounting, 1, 95-111.

Silverman, D. (Ed.). (1997) Qualitative research: Theory, method and practice. London, UK: Sage.

Stephenson, N., \& Papadopoulos, D. (2006) Analysing everyday experience: Social research and political change. New York, NY: Palgrave Macmillan. 
Tinker, A. M., Lehman, C., \& Neimark, M. (1991) Falling down the hole in the middle of the road: Political quietism in corporate social reporting. Accounting, Auditing \& Accountability Journal, 4(1), 28-54.

Watson, T. J. (1995) Rhetoric, discourse and argument in organizational sense making: A reflexive tale. Organization Studies, 16(5), 805-821.

Watson, T. J. (2008) Mighty McManus: Mystery myth and modernity. In M. Kostera (Ed.), Organizational olympians: Heroes and heroines of organizational myths (pp. 142-154). Basingstoke, UK: Palgrave MacMillan.

Wolcott, H. F. (1994) Transforming qualitative data: Description, analysis, and interpretation: Thousand Oaks, CA: Sage.

Yin, R. K. (2003) Case study research: Design and methods $\left(3^{\text {rd }}\right.$ ed.). Thousand Oaks, CA: Sage.

Zhuang, J., Gunatilake, H., Nilmi, Y., Khan, M. E., Bracey, P., \& Huang, B. (2009) Financial sector development, economic growth, and poverty reduction: A literature review. ADB Economics Working Paper Series, October (No. 173), pp. 1-32. 
Appendix 1

Primary data-collection techniques, timing; nature \& amount of data collected from different participants

\begin{tabular}{|c|c|c|c|c|c|c|}
\hline \multirow{2}{*}{\multicolumn{2}{|c|}{ TECHNIQUES }} & \multirow{2}{*}{$\begin{array}{l}\text { Initial } \\
\text { Telephone } \\
\text { Interview } \\
\text { (i) }\end{array}$} & \multirow{2}{*}{$\begin{array}{c}\text { Descriptive type } \\
\text { Questions } \\
\text { (1) }\end{array}$} & \multicolumn{3}{|c|}{ Series of Short Interviews (ii) } \\
\hline & & & & E-mails & Chats & Phone \\
\hline \multicolumn{2}{|l|}{ When } & June 2006 & July-August 2006 & \multicolumn{3}{|c|}{ September 2006} \\
\hline \multirow{5}{*}{$\begin{array}{l}\text { Amount of } \\
\text { data: } \\
\text { Approximate } \\
\text { No. of } \\
\text { Minutes/Wor } \\
\text { ds }\end{array}$} & \multirow[t]{3}{*}{ Case I } & & & \multicolumn{3}{|r|}{3 Calls } \\
\hline & & $\mathrm{N} / \mathrm{A}$ & 650 words & 13 & Once & 45 minutes \\
\hline & & & & \multicolumn{3}{|r|}{4 calls } \\
\hline & Case II & 26 Minutes & 530 words & 12 & Twice & 45 minutes \\
\hline & $\begin{array}{l}\text { Cross- } \\
\text { checking; All } \\
\text { cases }\end{array}$ & 105 Minutes & 250 words & 41 & Nil & $\begin{array}{l}30 \text { calls } \\
62 \text { minutes }\end{array}$ \\
\hline Nature of dato & & $\begin{array}{l}\text { Background } \\
\text { information of } \\
\text { the bank/credit } \\
\text { applicant, nature } \\
\text { of involvement of } \\
\text { the participant }\end{array}$ & $\begin{array}{l}\text { Basic information on } \\
\text { participants' } \\
\text { experience on credit } \\
\text { decisions considered }\end{array}$ & \multicolumn{3}{|c|}{$\begin{array}{l}\text { Friendly chat with a view to design } t \\
\text { analytical-type questionnaire to obt } \\
\text { more explanations on the credit } \\
\text { decisions and to obtain critical analyt } \\
\text { data through cross-questioning }\end{array}$} \\
\hline
\end{tabular}




\section{Interview Guideline (1)}

1. Please identify and provide details; credit amount, project description and application process (you are free to use fictitious names) for a credit applicant where you are well aware of the credit application process followed.

2. Was it successful?

3. Did the credit applicant attempt to approach a higher authority to influence the loan officers who were undertaking the formal credit process? How (by what methods) did the credit applicant approach the decision-makers?

4. How, and to what extent, was the credit applicant accommodated by the decision-makers and what methods were followed?

5. Please describe the the project proposal in detail in relation to the general economic environment in Sri Lanka?

6. Please describe the loans negotiation processes in the form of dialogue, if you can recall them?

7. What methods were used to present those projects to the decision-makers?

8. What methods did the borrower use to convince the decision-makers? Please indicate why you believe the bank decision-makers accommodated the loan (if you feel comfortable answering this question).

9. What were the immediate results of the credit decision?

10. Please describe the present situation of the enterprise? Does it service the loan/s? 
Interview Guideline (2); Analytical questions

\section{a) The approach and methods used by the borrower}

Why did the credit applicant approach the chairperson directly?

- Was it because he was powerful?

- Was it because he was rich?

- Was it because he had the access to, or had, the network?

- Had the applicant tried formal methods before?

What was the outcome of such approaches?

In the case of being denied credit, did the credit applicant attempt to approach the decision-makers informally? Was it successful? If not, why not?

\section{b) The approach and the methods used by the lender}

Why did the bank accommodate the credit applicant informally?

- Was the project financially feasible?

- Because of technical reasons such as excess liquidity?

- Because the decision-maker was deceptively guided by the capable credit applicant?

- Was it for personal gratification?

- Was it on sympathetic/patriotic/nationalistic grounds and/or based on social responsibility?

- Was it because of a personal relationship?

- Was the decision influenced by the ego of the decision-maker?

- Did the organisational structure force the decision-maker to make such decisions?

- Have the SME government financing schemes had any impact on this decision?

c) The influencing factors

Please comment on the following factors as contributing or acting as roadblocks towards the decision-making process for this decision:

- Organisation structure

- Poor management skills of the relevant bank officers

- Nationalistic or patriotic attitudes 
- Egoistic motives

- Government policies on entrepreneurship development

- Government policies in SME financing

d) The decision-making process

Please critically analyze the decision-making process and comment on the following questions:

- Was it quick?

- Was it after following proper banking policies and procedures?

- Was it based on cash flows and proper credit evaluations?

- Were decision-makers rewarded as a result of those decisions?

e) Concluding remarks

Please feel free to express your views on this credit application with regard to the social networks and economic and social power of individuals involved.

Also, can you express your views on the impact of such credit decisions on economic development and addressing poverty problems in Sri Lanka? 


\section{Appendix 2}

Summary of the analysis of case studies data

\begin{tabular}{|l|l|l|}
\hline & \multicolumn{1}{|c|}{ Case study I: Tony } & \multicolumn{1}{c|}{ Case study II: Silva } \\
\hline Project & $\begin{array}{l}\text { Large-scale credit for a } \\
\text { garment manufacturing } \\
\text { company struggling with lack } \\
\text { of orders and liquidity } \\
\text { problems. }\end{array}$ & $\begin{array}{l}\text { Small-scale credit, an up-and-coming } \\
\text { janitorial-service enterprise } \\
\text { struggling with loss of business and } \\
\text { with liquidity problems. }\end{array}$ \\
\hline Approach & $\begin{array}{l}\text { Casual, informal and personal. } \\
\text { Both the credit decision- } \\
\text { maker and the client are } \\
\text { socially powerful } \\
\text { businesspersons. }\end{array}$ & $\begin{array}{l}\text { First, formal and accommodated. } \\
\text { Then, informal and accommodated. } \\
\text { Then, formal and rejected. }\end{array}$ \\
\hline Issues & $\begin{array}{l}\text { Client was under threat of } \\
\text { foreclosure and redundancy. } \\
\text { Threat of redundancy of } \\
\text { 25,000 workers. }\end{array}$ & $\begin{array}{l}\text { A big competitor penetrating into } \\
\text { the business. } \\
\text { Soured relationship between bank } \\
\text { officers and the client. } \\
\text { Socially, applicant is less influential. }\end{array}$ \\
\hline Negotiation & Friendly. Quick. & $\begin{array}{l}\text { Treated differently by different } \\
\text { decision-makers, only one of whom } \\
\text { was genuinely sympathetic. }\end{array}$ \\
\hline Decision & $\begin{array}{l}\text { Without formal evaluation. } \\
\text { Granted over the table. }\end{array}$ & $\begin{array}{l}\text { First, formal and granted, then } \\
\text { informal and granted, and finally, } \\
\text { formal and declined. }\end{array}$ \\
\hline $\begin{array}{l}\text { Explanation or } \\
\text { Justification }\end{array}$ & $\begin{array}{l}\text { Sympathetic and patriotic } \\
\text { grounds. } \\
\text { Business development drive. }\end{array}$ & $\begin{array}{l}\text { First, personal benefits, error } \\
\text { rectifying and reciprocate. Then rigid } \\
\text { application of rules. }\end{array}$ \\
\hline
\end{tabular}




\section{Highlights}

- The paper uses the tools of Bourdieu and his distinction between the dominant and the dominated (symbolic violence) and how that influences habitus (and therefore practice) to understand the accounting and discrimination issues.

- While the accounting and discrimination literature tends to focus on how accounting serves for the class struggles and slavery, race and gender discrimination, the case studies through the auto-ethnography of bank practices presented in this paper attempt to understand the accounting and discrimination issues in the field of bank lending.

- Findings of the paper demonstrate how individuals with given habitus behave and follow given strategies to deploy rational accounting systems at micro level and create the outcome of creating and reinforcing discrimination. 